\title{
Assessment of changes in crystallization properties of pressurized milk fat ${ }^{1}$
}

\author{
Bogusław Staniewski, ${ }^{2}$ Michał Smoczyński, Katarzyna Staniewska, Maria Baranowska, \\ Katarzyna Kiełczewska, and Justyna Zulewska \\ Faculty of Food Sciences, University of Warmia and Mazury, Oczapowskiego 7, 10-719 Olsztyn, Poland
}

\begin{abstract}
The aim of the study was to demonstrate the use of fractal image analysis as a possible tool to monitor the effect of pressurization on the crystallization pattern of anhydrous milk fat. This approach can be useful when developing new products based on milk fat. The samples were subjected to different hydrostatic pressure (100, $200,300$, and $400 \mathrm{MPa})$ and temperature $\left(10\right.$ and $\left.40^{\circ} \mathrm{C}\right)$ treatments. The crystallization microphotographs were taken with a scanning electron microscope. The image analysis of scanning electron microscope photographs was done to determine a fractal dimension. Milk-fat pressurization under the applied parameters resulted in slight, but statistically significant, changes in the course of crystallization curves, related to the triacylglycerol fraction crystallizing in the lowest temperature (I exothermic effect). These changes were dependent on the value of pressure but not dependent on the temperatures applied during the process of pressurization (at either 10 or $40^{\circ} \mathrm{C}$ ). In turn, significant differences were observed in crystallization images of milk-fat samples subjected to this process compared with the control sample. The results of additional fractal analysis additionally demonstrated the highest degree of irregularity of the surface of the crystalline form for the nonpressurized sample and the samples pressurized at 200 and $300 \mathrm{MPa}$ at $10^{\circ} \mathrm{C}$. The lowest value of fractal dimension-indicative of the least irregularity - was achieved for the fat samples pressurized at $400 \mathrm{MPa}$, $10^{\circ} \mathrm{C}$ and at $100 \mathrm{MPa}, 40^{\circ} \mathrm{C}$. The possibilities of wider application of the fractal analysis for the evaluation of effects of parameters of various technological processes on crystallization properties of milk fat require further extensive investigations.
\end{abstract}

\footnotetext{
Received June 26, 2014.

Accepted January 2, 2015.

${ }^{1}$ Use of names, names of ingredients, and identification of specific models of equipment is for scientific clarity and does not constitute any endorsement of product by authors or University of Warmia and Mazury.

${ }^{2}$ Corresponding author: bostuwm@gmail.com
}

Key words: milk fat, triacylglycerol composition, pressurization, physical and crystallization properties, fractal analysis

\section{INTRODUCTION}

Milk fat remains the subject of interest to the consumers and many research groups (Breitschuh and Windhab, 1998; Datta and Deeth, 1999; Frede and Buchheim, 2000; Herrera and Hartel, 2000; Lopez et al., 2001, 2006; Shi et al., 2001; Roginski et al., 2003; Fox and McSweeney, 2006; Verret et al., 2009; Rønholt et al., 2012). Use of milk fat as a food component is affected by seasonal and regional variability of its physical properties. Many studies showed that the physical properties of milk fat depend largely on the composition of its main constituent, triacylglycerols (TAG), given the type and position of esterified FA (Shi et al., 2001; Wright and Marangoni, 2006). Consequently, the range of milk-fat melting temperatures is very broad and usually is between -40 and $+40^{\circ} \mathrm{C}$. Various polymorphic forms of crystallizing TAG $\left(\gamma, \alpha, \beta^{\prime}, \beta\right)$ might also affect the physical properties of milk fat (Breitschuh and Windhab, 1998; Wright and Marangoni, 2006; Lopez and Ollivon, 2009). The knowledge of crystallization kinetics is, therefore, essential for monitoring the technological parameters of production of many foods based on milk fat, especially those influencing their functional properties, in particular texture (Herrera and Hartel, 2000; Roginski et al., 2003; Wright and Marangoni, 2006). This may be particularly significant to dairy products with the highest fat content; that is, butter and anhydrous milk fat, which is more often applied in various branches of the food industry. Apart from milk-fat composition (including the content of incomplete acylglycerols), the key parameter that affects rheological properties of such products is the ratio of solid and liquid phases of milk fat at given temperature (Shi et al., 2001; Foubert et al., 2004). On the micro scale, these characteristics may be determined by the crystallization image that covers not only size of the crystals but also their quality, as indicated by their shape and even acylglycerol composition. 
Many possibilities for milk-fat modification are offered by existing technologies. A significant range of modifications of the physicochemical properties of milk fat may be ensured by such processes as fractionation (Van Aken et al., 1999; Lopez et al., 2006), hydrogenation (Augustin and Verteeg, 2006), and esterification (Tynek and Ledóchowska, 2003; Wright and Marangoni, 2006). The composition and physical properties of milk fat may as well be modified by the nutritional methods; that is, cow feed supplementation with socalled protected lipids, which prevent biohydrogenation of unsaturated FA in the rumen. Pressurization seems to be an interesting physical method applied to modify milk-fat properties (Buchheim et al., 1996; Datta and Deeth, 1999; Huppertz et al., 2002; Trujillo et al., 2002).

Initial studies focused on the size of fat globules and crystallization processes occurring after pressurization of milk or cream (Buchheim et al., 1996; Frede and Buchheim, 2000; Gervilla et al., 2001; Fox and McSweeney, 2006; Verret et al., 2009). It was shown that the application of pressure in the range of 100 to $500 \mathrm{MPa}$ at 25 and $50^{\circ} \mathrm{C}$ to sheep milk resulted in an increased content of fat globules with diameters of 1 to $2 \mu \mathrm{m}$ and a decreased content of fat globules with diameters of 2 to $10 \mu \mathrm{m}$. However, an opposite effect was noticed when pressurization was at $4^{\circ} \mathrm{C}$ (Gervilla et al., 2001). These studies demonstrated also that pressurization in this pressure range contributed to decreasing content of FFA. Pressurization at 100 to $500 \mathrm{MPa}$ was shown to facilitate a decrease in physical ripening time of cream for butter production (Buchheim et al., 1996). The authors hypothesized that it is due to the shift of melting and crystallization temperatures of the main milk-fat fractions toward higher values (Buchheim et al., 1996). Verret et al. (2009) suggested that such an effect might result from crystallization of the main TAG fractions in various polymorphic forms.

Extensive studies have been conducted on the effect of pressurization on the composition and crystallization properties of pure milk fat, its fractions, and mixtures with other fats under various conditions of crystallization and by using different analytical methods (Frede and Buchheim, 2000; Staniewski et al., 2012). Many research techniques may be applied to evaluate the effect of different modification methods on milk-fat crystallization images. These may include very simple intermediate methods evaluating the final melting point of TAG in the analyzed sample or considerably more informative curves of crystallization and melting plotted by using differential scanning calorimetry (DSC), which additionally enables precise evaluation of changes in the content of the solid phase of fat in the function of temperature changes (Breitschuh and Windhab, 1998; Lopez and Ollivon, 2009; Fredrick et al., 2011; Rønholt et al., 2012). The latter may also be analyzed with the use of nuclear magnetic resonance (Herrera and Hartel, 2000; Foubert et al., 2004; Martini et al., 2005). Special significance in the analysis of fat crystallization image (including milk fat) is, however, ascribed to microscopic methods that include optical microscopy and-increasingly often-also electron microscopy. In turn, polymorphic changes may be analyzed with the use of X-ray diffraction (Van Aken et al., 1999; Lopez et al., 2001; Martini and Herrera, 2002; Lopez et al., 2006).

Nevertheless, multiple processes ongoing in nature lead to the formation of "apparently" unordered structures. Quantitative comparison of such objects may be difficult, and their descriptive characteristics are often imprecise and biased. This is the case with microscopic images of fats crystallization, and use of mathematical algorithms with specific parameters characterizing the structure may allow for their precise description. One of such parameters may be the fractal dimension.

Fractals have a self-similar pattern, which means they have the same structural characteristics irrespective of observation scale (Mandelbrot, 1982). Although they are ideal mathematical structures, it is possible to apply the concept of fractal geometry in the case of natural objects occurring in nature. To some extent, these structures may demonstrate some fractal characteristics, and the determined fractal dimension (often called "apparent" dimension) may well characterize these structures (Peleg, 1993). Depending on the research methods applied, it may characterize the rate of filling of an observed volume by the studied substance or the rate of filling of a surface by a ragged line; that is, of the analyzed object (Leman et al., 2005; Smoczyński and Baranowska, 2014). The fractal dimension expresses a correlation between the mass of the fractal object and its dimension. The only difference between the ordinary correlation between mass and size is the exponent, which in the case of fractal objects is an integer.

The aim of this study was to determine the effect of pressurization on crystallization properties of milk fat based on the fractal analysis of the crystallized sample.

\section{MATERIALS AND METHODS}

\section{Experimental Material}

The experimental material was anhydrous milk fat. The milk for milk-fat production came from stallfeeding cows. The milk fat was obtained from "extra" type butter produced in one of the dairy plants located in northeastern Poland. The butter was melted at a temperature 55 to $60^{\circ} \mathrm{C}$, and then the milk fat was 
decanted from above plasma and filtrated (at $60^{\circ} \mathrm{C}$ ) through Whatman blotting paper of medium filtration rate filled with calcined anhydrous sodium sulfate.

\section{Conditions of Pressurization}

The milk fat was subjected to hydrostatic pressurization using a U 4000/40 device (Unipress Equipment, Warsaw, Poland). Four levels of pressure (100, 200, 300 , and $400 \mathrm{MPa}$ ) and 2 levels of temperature (10 and $40^{\circ} \mathrm{C}$ ) were applied during the pressurization process. The process was held for $15 \mathrm{~min}$. An isothermal pressurization chamber provided temperature stability of the process.

The samples not subject to the pressurization process were used as a control. They were studied under the same temperature conditions as the corresponding experimental samples. All samples after pressurization were kept overnight and analyzed on the next day.

\section{Analysis of TAG Composition}

The contribution of particular groups of TAG in examined samples was determined using gas chromatography (Żegarska, 1988). First, fat was dissolved in ether and then analyzed using PU 4600 gas chromatograph (Unicam, Cambridge, UK) with a flame-ionization detector (Unicam). Separation was run on a glass column filled with 3\% OV-17 (Alltech Assoc. Ltd., Camforth, UK) on Chromosorb W (HP) 80/100 mesh (40 cm in length and $4 \mathrm{~mm}$ of internal diameter; Alltech Assoc. Ltd.) with argon as a carrier gas (flow rate $50 \mathrm{~mL}$ / min). The separation was carried out in a temperature range of from 230 to $340^{\circ} \mathrm{C}$ with a gradient $6^{\circ} \mathrm{C} /$ min. The temperatures of detector and injector were 340 and $330^{\circ} \mathrm{C}$, respectively. The results were expressed as percentage of individual TAG content in total TAG (weight \%).

\section{Analysis of Physical Properties-DSC}

The physical properties of milk-fat samples analyzed using DSC Q10 calorimeter (TA Instruments, New Castle, DE) included melting point and coagulation temperature of the main TAG fractions. The curves were generated with Universal Analysis 2000 software (TA Instruments). The parameters were determined based on the peaks on curves depicting the endothermic and exothermic effects, respectively. The following procedure was applied during milk-fat analysis: the sample was fast heated to a temperature of $+80^{\circ} \mathrm{C}\left(5^{\circ} \mathrm{C} / \mathrm{min}\right)$, then kept at $+80^{\circ} \mathrm{C}$ for $5 \mathrm{~min}$, cooled to $-50^{\circ} \mathrm{C}$ at a rate of $5^{\circ} \mathrm{C} / \mathrm{min}$, kept at $-50^{\circ} \mathrm{C}$ for $15 \mathrm{~min}$, and then heated again to $+70^{\circ} \mathrm{C}$ at a rate of $5^{\circ} \mathrm{C} / \mathrm{min}$.

\section{Microscopic Analysis with Image Analysis}

For more in-depth analysis of crystallization properties, the samples of pressurized fat and the control sample were subject to further observation in a Quanta 200 scanning electron microscope (FEI Company, Eindhoven, the Netherlands) and to fractal analysis. Before scanning electron microscope analysis, the samples were transferred to a thermal chamber (type ICP 500, Memmert, Germany) and kept therein at $10^{\circ} \mathrm{C}$ for 24 h. The analysis was carried out at $10^{\circ} \mathrm{C}$. A series of microphotographs was taken for each sample at various magnifications. The resultant images of the microstructure of the fat-crystal surface were analyzed using NisElements Basic Research software (Nikon Corporation, Tokyo, Japan). First, contrast of the analyzed images was increased to the maximum using the following settings of gray-hue cut-off points: high $=106$ and low $=105$. Then, closed shapes (objects) of various sizes (small and large) were marked on the obtained images, and their perimeter $(\mathrm{P})$ and area (A) were measured. Next, fractal dimension $\left(D_{L}\right)$ was determined from log $\mathrm{A}=f[\log (\mathrm{P})]$ dependency and a slope of the achieved straight line.

\section{Statistical Analysis}

To determine significant differences existed, all data were subjected to a 2-way ANOVA at a significance level 0.05 using Statistica version 10.0 software for Windows (Statistica 2011, StatSoft Inc., Tulsa, OK). Regression equations were determined, and coefficients of determination were computed. The results are presented as mean values of 2 parallel repetitions.

\section{RESULTS AND DISCUSSION}

The adopted experimental model enabled a 2-way ANOVA of the effect of 5 pressure levels (including the zero level for the nonpressurized sample) and 2 temperature levels applied during pressurization.

\section{TAG Composition}

The chemical composition of milk fat influences its many significant properties including rheological characteristics, solid-to-liquid phase ratio, melting point, fat behavior during crystallization and melting, and its crystallization image (Wright and Marangoni, 2006).

The analysis of FA composition demonstrated that milk-fat characteristics were typical of the stall feeding period (Figure 1). The following TAG contributions were found in the samples: 6.99, 10.88, 11.36, 


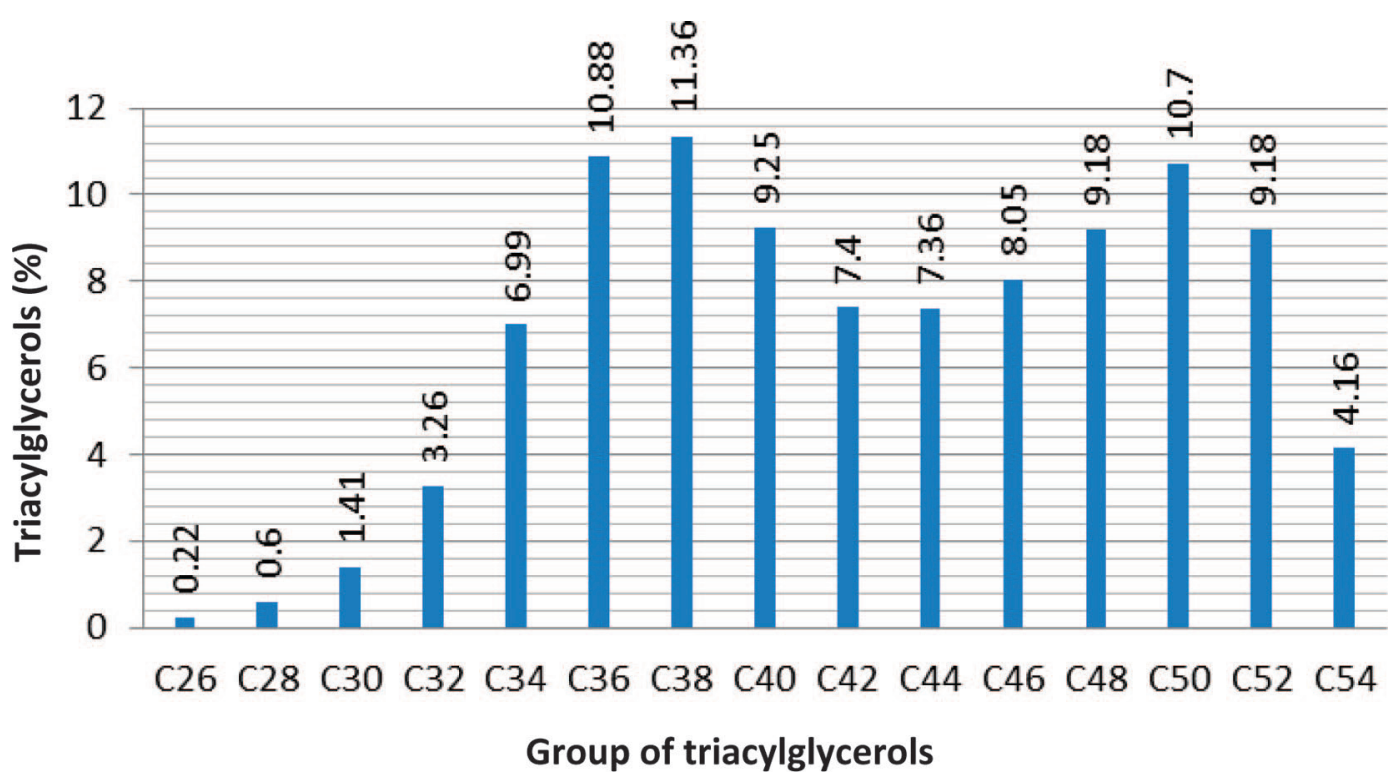

Figure 1. Composition of triacylglycerols in milk-fat samples (weight \%). Color version available online.

9.25, 10.70, and $9.18 \%$ for TAG C34, TAG C36, TAG C38, TAG C40, TAG C50, and TAG C52, respectively. Similar results were found in the research carried out by Żegarska (1988) and Juśkiewicz et al. (1993). The results for the nonmodified fat (control sample) are also consistent with findings reported by Staniewski (2000) and Staniewski et al. (2012) for the highest contribution of individual TAG in fat of winter butter. The most significant similarities were noted in the contribution of TAG C36, TAG C38, TAG C50, and TAG C52. Similar results of TAG composition in milk fat were reported by Adamska and Rutkowska (2012) and by Smiddy et al. (2012).

\section{Physical Properties-DSC}

From the technological and consumer perspective, the melting point is an important indicator of the physical properties of fats; that is, milk fat. It depends on FA composition of TAG and on the position of double bonds, chain branching, or the position of FA residues in TAG (Roginski et al., 2003; Fox and McSweeney, 2006). It is also affected by crystallization of TAG fractions with the highest melting point. It is worthwhile to note that the melting point has a significant effect on the functional properties (i.e., spreadability) of butter and milk-fat spreads.

However, the melting point does not provide complete data on crystallization properties of fat. It only informs on the melting of the most fusible TAG fraction in the analyzed sample. Considerably more information about these physical properties of fat, which are very significant from the technological point of view, is provided by the thermal analysis methods, including DSC.

The results from DSC of analyzed samples are presented in Figure 2. An increase in the temperature, pressure, or both of the pressurization process resulted in an increase of crystallization temperature of the lowest crystallizing milk-fat fractions. One important goal of this experiment was to determine to what extent the pressurization process carried out in a wide range of pressures $(100,200,300$, and $400 \mathrm{MPa})$ and at temperatures of 10 and $40^{\circ} \mathrm{C}$ would affect the characteristics of melting and crystallization curves compared with the control sample (nonpressurized). Interpretation of the obtained results is, however, inexplicit. The comparison of the main endo- and exothermic effects and additional statistical analysis (ANOVA) demonstrated that the applied pressurization conditions had practically no effect on changes in temperatures of the main endothermic effects on melting curves of the pressurized samples, regardless of the value of both pressure and temperature of the process. In turn, a small but significant $(P<$ $0.05)$ shift was observed toward higher temperatures of the I exothermic effect (related to the milk-fat fraction crystallizing in the lowest temperature) that occurred during melting of pressurized samples under conditions of DSC measurement. As indicated by the results of the ANOVA, this effect was additionally influenced by pressure value but did not depend significantly $(P>$ 0.05 ) on temperature of the pressurization (Tables 1 and 2).

It ought to be strongly emphasized that the extent of changes observed in the course of crystallization 
Table 1. Main endo- and exothermic effects on crystallization and melting curves plotted for samples before and after pressurization (I, II, III-successive thermic effects)

\begin{tabular}{|c|c|c|}
\hline Type of milk & $\begin{array}{l}\text { Exothermic effect } \\
\text { on crystallization } \\
\text { curves }\left({ }^{\circ} \mathrm{C}\right)\end{array}$ & $\begin{array}{l}\text { Endothermic effects } \\
\text { on melting curves }\left({ }^{\circ} \mathrm{C}\right)\end{array}$ \\
\hline Fat before pressurization & 7.8 (I), 13.4 (II) & 9.4 (I), 15.9 (II), 32.4 (III) \\
\hline $10^{\circ} \mathrm{C}, 100 \mathrm{MPa}$ & $8.2(\mathrm{I}), 13.8$ (II) & 9.0 (I), 16.1 (II), 32,4 (III) \\
\hline $10^{\circ} \mathrm{C}, 200 \mathrm{MPa}$ & $8.4(\mathrm{I}), 13.4$ (II) & 9.2 (I), 16.1 (II), 32.4 (III) \\
\hline $10^{\circ} \mathrm{C}, 300 \mathrm{MPa}$ & $8.2(\mathrm{I}), 14.0$ (II) & 9.03 (I), 15.9 (II), 32.4 (III) \\
\hline $10^{\circ} \mathrm{C}, 400 \mathrm{MPa}$ & $8.2(\mathrm{I}), 13.8$ (II) & 9.2 (I), 15.9 (II), 32.4 (III) \\
\hline $40^{\circ} \mathrm{C}, 100 \mathrm{MPa}$ & 8.4 (I), 13.6 (II) & 9.2 (I), 15.9 (II), 32.4 (III) \\
\hline $40^{\circ} \mathrm{C}, 200 \mathrm{MPa}$ & $8.2(\mathrm{I}), 13.6$ (II) & 9.2 (I), 15.9 (II), 32.2 (III) \\
\hline $40^{\circ} \mathrm{C}, 300 \mathrm{MPa}$ & 8.4 (I), 13.6 (II) & 9.2 (I), 15.9 (II), 32.4 (III) \\
\hline $40^{\circ} \mathrm{C}, 400 \mathrm{MPa}$ & $8.2(\mathrm{I}), 14.0$ (II) & 8.8 (I), 15.9 (II), 32.4 (III) \\
\hline
\end{tabular}

and melting curves cannot be determined as significant, compared with effects of other methods applied to modify the physical properties of fats. Considerably more tangible changes were observed even as a result of milk-fat fractionation with and without a solvent (Van Aken et al., 1999; Staniewski, 2000). In the study of van Aken et al. (1999), the shifts of peaks characterizing the main endothermic effects on melting curves of the most different fractions reached even 20 to $30^{\circ} \mathrm{C}$ after fractionation with acetone used as a solvent and ca. $20^{\circ} \mathrm{C}$ in the case of dry fractionation.

The significant changes in the physicochemical properties of fat may also be achieved upon enzymatic esterification of both pure fats and, even more often, fat mixes (Augustin and Verteeg, 2006). A study by Tynek and Ledóchowska (2003) demonstrated a de-

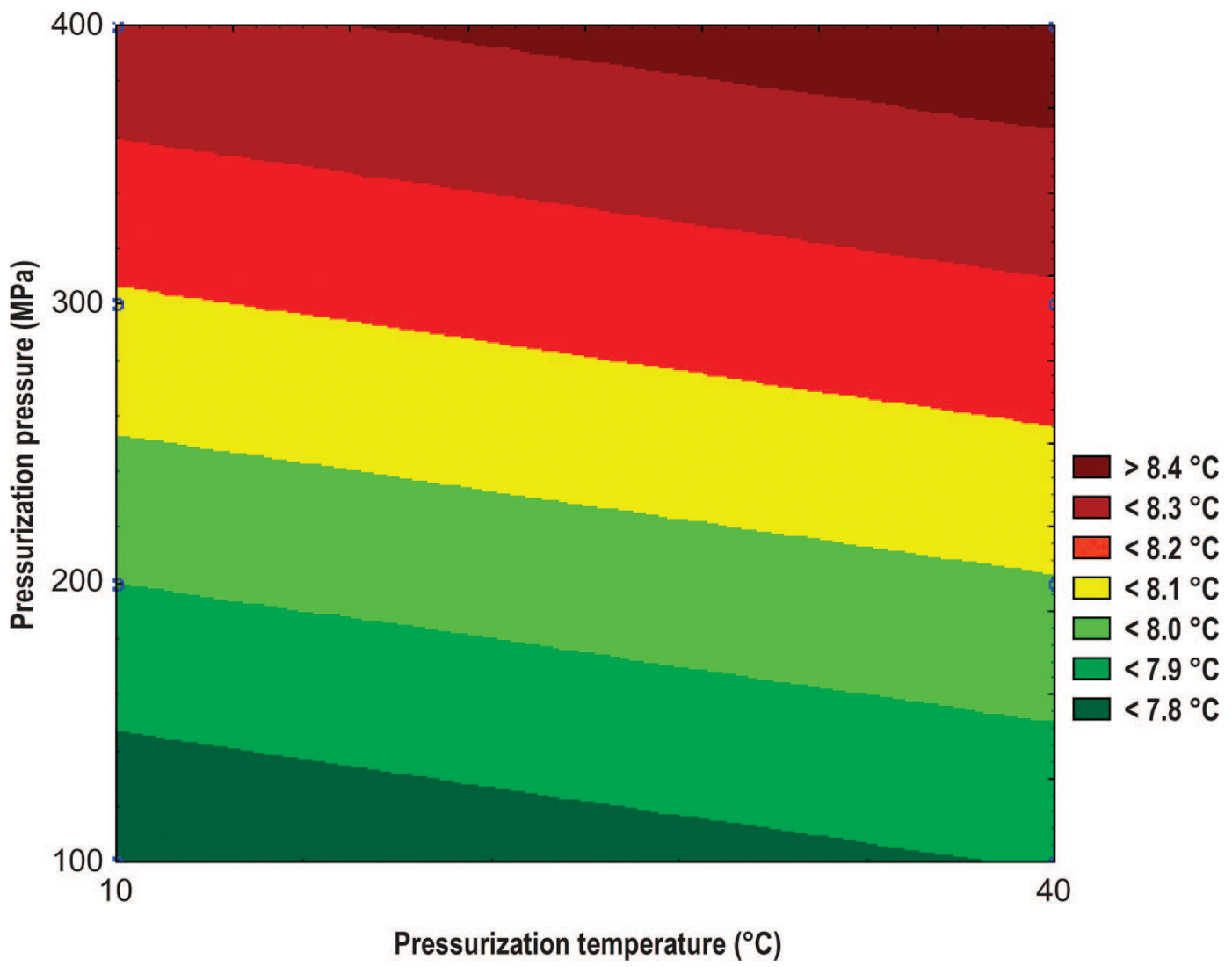

Figure 2. Variability of temperature and exothermic effect affected by pressure and temperature applied during pressurization. Color version available online. 
Table 2. Effect of pressure and temperature of pressurization on the parameters of the main exo- and endothermic effects-results of 2-way ANOVA ${ }^{1}$

\begin{tabular}{llllll}
\hline & \multicolumn{2}{l}{ Exothermic effect on crystallization curves $\left({ }^{\circ} \mathrm{C}\right)$} & & Endothermic effects on melting curves $\left({ }^{\circ} \mathrm{C}\right)$ \\
\cline { 2 - 3 } $\begin{array}{l}\text { Thermic } \\
\text { effect }\end{array}$ & $\begin{array}{lllll}\text { Effect of pressure } \\
\left(\mathrm{F}_{\text {tab }}=6.3882\right)\end{array}$ & $\begin{array}{l}\text { Effect of temperature } \\
\left(\mathrm{F}_{\text {tab }}=7.7086\right)\end{array}$ & & $\begin{array}{l}\text { Effect of pressure } \\
\left(\mathrm{F}_{\text {tab }}=6.3882\right)\end{array}$ & $\begin{array}{l}\text { Effect of temperature } \\
\left(\mathrm{F}_{\text {tab }}=7.7086\right)\end{array}$ \\
\hline I & $\mathrm{F}_{\text {calc }}=6.7142^{*}$ & $\mathrm{~F}_{\text {calc }}=0.2857$ & & $\mathrm{~F}_{\text {calc }}=1.5333$ & $\mathrm{~F}_{\text {calc }}=0.0000$ \\
II & $\mathrm{F}_{\text {calc }}=2.5294$ & $\mathrm{~F}_{\text {calc }}=0.1176$ & & $\mathrm{~F}_{\text {calc }}=1.0000$ & $\mathrm{~F}_{\text {calc }}=2.6666$ \\
III & & & $\mathrm{F}_{\text {calc }}=1.0000$ & $\mathrm{~F}_{\text {calc }}=1.0000$ \\
\hline
\end{tabular}

${ }^{1} \mathrm{~F}_{\mathrm{tab}}=\mathrm{F}$-value based on the table; $\mathrm{F}_{\text {calc }}=$ calculated $\mathrm{F}$-value

*Statistically significant effect at $P=0.05$.

crease of melting point of milk fat and its mixes with sunflower oil as a result of enzymatic esterification with $s n-1,3$ Lipozyme IM. These differences ranged from 3 to $10^{\circ} \mathrm{C}$ depending on the type of fat mix subjected to esterification. Another highly effective method used for modification of physical properties of fats is blending (Staniewski, 2000; Augustin and Versteeg, 2006). In all discussions concerning the crystallization properties of pressurized milk fat, consideration should be given to the form of fat. Slightly different effect may be expected from pressurization of fat in the form of emulsion (Verret et al., 2009; Fredrick et al., 2011). Likewise, the studies of Fredrick et al. (2011) and Verret et al. (2009) showed no significant differences in temperature shifts of endothermic effects. In turn, the above studies demonstrated differences (accompanying sample melting) in changes of the solid phase content for the nonpressurized and pressurized samples.

\section{Microscopic Analysis with Image Analysis}

The differences in the course of melting and coagulation curves, especially at higher temperatures of the I exothermic effect for pressurized samples, were also demonstrated in the results of the microscopic analysis (Figure 3).

Visual changes were not noted in the fat samples with pressurization, but some differences may be observed analyzing crystallization images of fat before and after pressurization using a scanning electron microscope. The nonpressurized fat was characterized by even distribution of fat crystals that covered almost the entire image of the preparation subjected to microscopic examination (darker areas in the photos). It was noticed, however, that fat was not crystallized in the monolith form but appeared as a structure consisting of a vast number of flat crystalline structures with highly irregular edges and size of ca. $25 \mu \mathrm{m}$ (Figure 3 ).

\begin{tabular}{llcccc}
\hline Temperature & Milk fat & \multicolumn{3}{c}{ Milk fat after pressurization at } \\
\cline { 2 - 5 } $\begin{array}{l}\text { of } \\
\text { pressurization }\end{array}$ & $\begin{array}{l}\text { before } \\
\text { pressurization }\end{array}$ & $100 \mathrm{MPa}$ & $200 \mathrm{MPa}$ & $300 \mathrm{MPa}$ & $400 \mathrm{MPa}$ \\
\hline
\end{tabular}

$10^{\circ} \mathrm{C}$
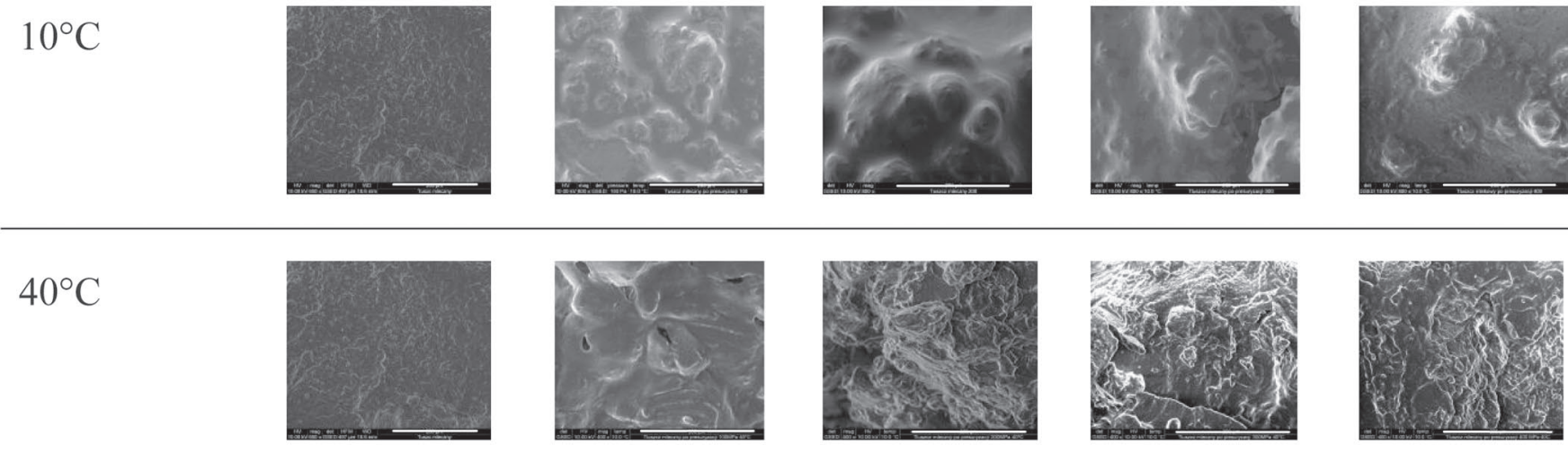

Figure 3. Effect of pressurization on changes in microscopic images of milk-fat sample crystallization. The white line on each image indicates a distance of $200 \mu \mathrm{m}$. 
Table 3. The results of fractal analysis of crystallization image for samples before and after pressurization

\begin{tabular}{lcc}
\hline Type of milk & $\begin{array}{c}\text { Fractal } \\
\text { dimension }\end{array}$ & $\mathrm{R}^{2}$ \\
\hline Fat before pressurization & 1.629 & 0.947 \\
Fat after pressurization at $100 \mathrm{MPa}, 10^{\circ} \mathrm{C}$ & 1.486 & 0.497 \\
Fat after pressurization at $200 \mathrm{MPa}, 10^{\circ} \mathrm{C}$ & 1.741 & 0.903 \\
Fat after pressurization at $300 \mathrm{MPa}, 10^{\circ} \mathrm{C}$ & 1.628 & 0.935 \\
Fat after pressurization at $400 \mathrm{MPa}, 10^{\circ} \mathrm{C}$ & 1.384 & 0.959 \\
Fat after pressurization at $100 \mathrm{MPa}, 40^{\circ} \mathrm{C}$ & 1.421 & 0.963 \\
Fat after pressurization at $200 \mathrm{MPa}, 40^{\circ} \mathrm{C}$ & 1.537 & 0.939 \\
Fat after pressurization at $300 \mathrm{MPa}, 40^{\circ} \mathrm{C}$ & 1.495 & 0.921 \\
Fat after pressurization at $400 \mathrm{MPa}, 40^{\circ} \mathrm{C}$ & 1.605 & 0.945 \\
\hline
\end{tabular}

More diversified crystalline structures were observed for the pressurized samples. The analysis of their microscopic images demonstrated that even a pressure treatment at $100 \mathrm{MPa}$ and $10^{\circ} \mathrm{C}$ affected crystallization of milk fat. The crystals had distinct heterogeneous protrusions of the surface reaching up to $50 \mu \mathrm{m}$. An increase in pressure caused successive surface diversification of crystals, mainly enlargements of the protrusions and additional irregularities. Significant enlargement of surface irregularities was observed in the microscopic image of the samples pressurized at $300 \mathrm{MPa}$.

The samples subjected to high-pressure treatment at $40^{\circ} \mathrm{C}$ were characterized by even more diversified microscopic images. Similar changes were observed as for the samples pressurized at $10^{\circ} \mathrm{C}$; however, further surface folding and breaking was noticed on the images. Such diversity may be explained by various intensity of pressure applied during pressurization on TAG molecules under conditions of higher or lower degree of crystallization or even under conditions of liquefied fat.

Because of difficulties in description and evaluation of unordered structures, the degree of unevenness and ragging of crystallization images of the analyzed fat samples was described with results of fractal analysis. Such results ensure unbiased characteristics of the surface unevenness degree based on the achieved fractal dimension. For fractal analysis, the images of the surface structure of milk fat were transformed into binary images with the maximum contrast. Afterward, the surface (A) and perimeter (P) were marked and measured for at least 100 to 150 objects for each type of fat. The plots of $\log \mathrm{A}-\log \mathrm{P}$ correlation were characterized by high coefficients of determination, ranging from 0.903 to 0.963 (Table 3). This parameter expressed the correctness of the applied mathematical model to obtained experimental results. The high values of correlation coefficients obtained for images analyzed at various magnifications indicate, to some extent, the similarity of the observed structures and specified degree of their ordering, typical of a given structure. The fractal dimension was computed from the slope of the straight line of $\log \mathrm{A}=f(\log \mathrm{P})$ function as $D_{L}=2 / a$, where $a$ denotes the slope of a straight line and $D_{L}$ denotes surface fractal dimension (Dziuba et al., 1999). An example of the correlation for milk fat before pressurization is presented in Figure 4. Higher fractal dimension is indicative of stronger ragging of the surface of the analyzed structures. Fractal dimensions and determination coefficients computed in this study are given in Table 3.

Fractal dimensions of the analyzed samples of milk fat ranged from 1.384 to 1.741 (Table 3). At pressures of 100,200 , and $300 \mathrm{MPa}$, higher values of fractal dimensions were obtained from milk fat pressurized at a temperature of $10^{\circ} \mathrm{C}$ than at $40^{\circ} \mathrm{C}$ (Table 3). Probably, at higher temperature a greater part of fat was in liquid form and became more susceptible to surface deformation of shape upon pressure treatment, which in turn resulted in lesser ragging of the edges of the observed shapes and smoothing of their contours. As a result, lower values of fractal dimensions for the samples pressurized at $40^{\circ} \mathrm{C}$ (Table 3) were observed. However, a lower value of fractal dimension was achieved at $10^{\circ} \mathrm{C}$ for the 400-MPa pressure treatment (Table 3). Probably, the effect of high pressure was so significant that it contributed to the smoothing of contours of the observed shapes, despite of the fact that at a temperature of $10^{\circ} \mathrm{C}$, a considerable part of fat was remaining in the crystallized form. The high value of the fractal dimension of the samples treated at $40^{\circ} \mathrm{C}$ and $400 \mathrm{MPa}$ is unclear. The high pressure could cause both the smoothening of outlines by the effect on liquefied fraction (during pressurization) and the uncovering of fractions remaining in the crystallized form. The obtained results of fractal analysis may seem inexplicit considering the complexity of occurring effects and analyzed material. Nevertheless, such an approach to the characteristics of complex processes or the observed irregular shapes (for which verbal description is sometimes difficult) may enable complete characteristics of the occurring effects and their comparison with the use of one parameter; for example, fractal dimension. It ought to be remembered that difficulties emerging during description of microscopic images of fat samples crystallization, both these obtained using an electron microscope and frequently applied optical microscopy, may to some extent be determined by differences in temperature conditions applied in the microscopic analysis and occurring during technological processes described with its use (Staniewski, 2000; Tietz and Hartel, 2000; Lopez and Ollivon, 2009). 


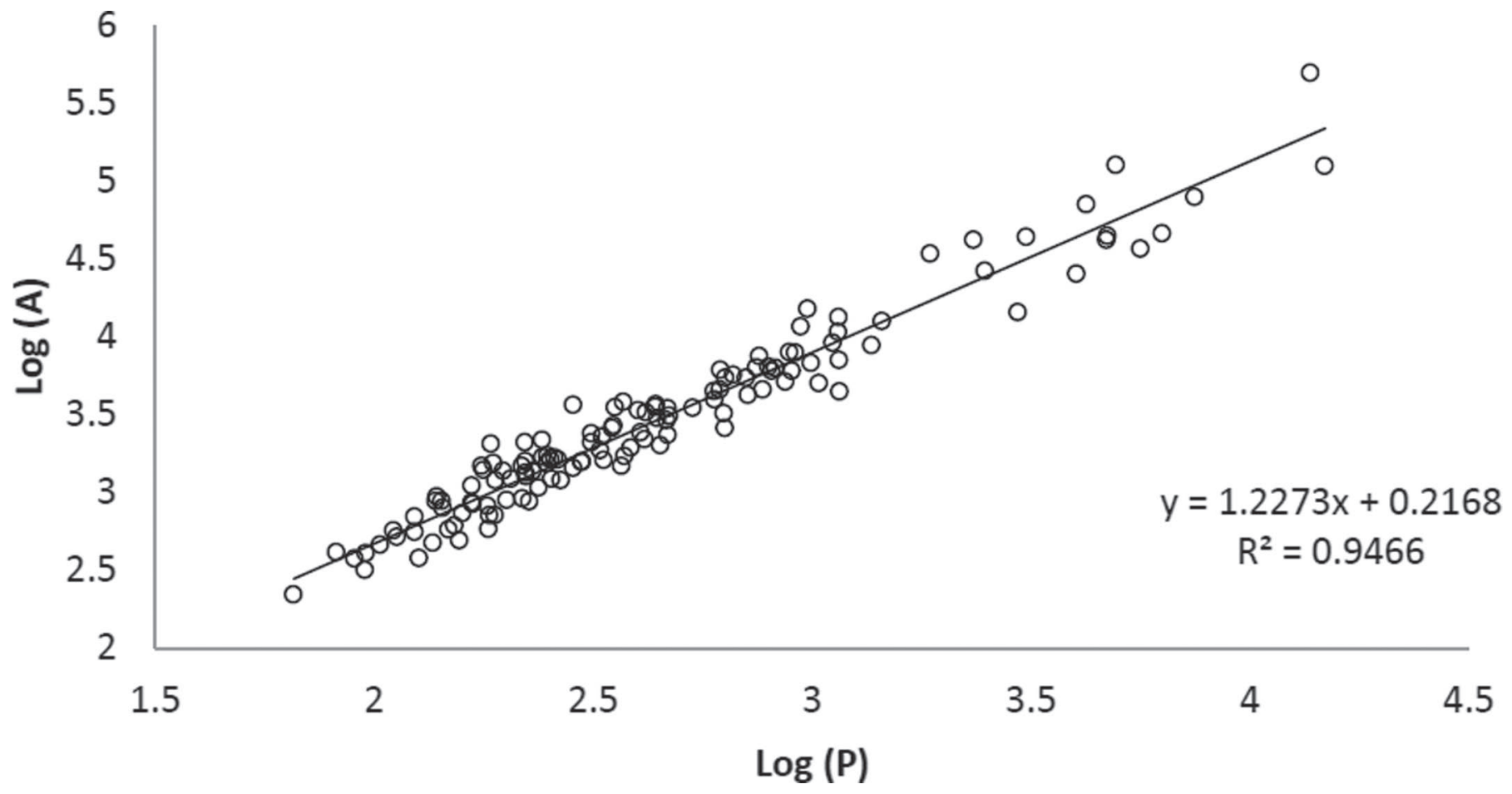

Figure 4. A sample of a $\log$ Area $=\mathrm{f}(\log$ Perimeter $)$ dependency for milk fat before pressurization used for calculation of the fractal dimension.

\section{CONCLUSIONS}

The applied parameters of milk-fat pressurization (100-400 MPa) resulted in small but significant changes in the course of crystallization curves regarding the I exothermic effect. It was found that the effect of these changes depends on the value of pressure applied during pressurization. Pressurization temperatures had no effect (at either 10 or $40^{\circ} \mathrm{C}$ ). In turn, the study showed significant differences in crystallization images of milk fat subjected to pressurization compared with the control sample. The results of fractal analysis additionally demonstrated the highest degree of irregularity of the crystalline-form surface for the nonpressurized sample and the samples pressurized at 200 and $300 \mathrm{MPa}$ at $10^{\circ} \mathrm{C}$. The lowest value of fractal dimension-indicative of the least irregularity - was achieved for the fat samples pressurized at $400 \mathrm{MPa}, 10^{\circ} \mathrm{C}$ and at $100 \mathrm{MPa}$, $40^{\circ} \mathrm{C}$. The possibilities of wider application of the fractal analysis for the evaluation of effects of parameters of various technological processes on crystallization properties of milk fat require further extensive investigations.

\section{ACKNOWLEDGMENTS}

The scientific and technical assistance of University of Warmia and Mazury staff members Krystyna
Wiśniewska and Waldemar Brandt is greatly appreciated.

\section{REFERENCES}

Adamska, A., and J. Rutkowska. 2012. Sezonowe zmiany składu triacylogliceroli w tłuszczu mleka rasy simentalskiej. Żywność. Nauka. Technologia. Jakość. 5:145-154.

Augustin, M. A., and C. Versteeg. 2006. Milk fat: Physical, chemical and enzymatic modification. Pages 293-332 in Advanced Dairy Chemistry. Vol. 2: Lipids. P. F. Fox and P. L. H. McSweeney, ed. Springer, New York, NY.

Breitschuh, B., and E. J. Windhab. 1998. Parameters influencing cocrystallization and polymorphism in milk fat. J. Am. Oil Chem. Soc. 75:897-904.

Buchheim, W., K. Schrader, C. V. Morr, E. Frede, and M. Schutt. 1996. Effects of high pressure on the protein, lipid and mineral phase of milk. Heat treatments and alternative methods. Pages 202-213 in Int. Dairy Fed., Special Issue 9602. Int. Dairy Fed., Brussels, Belgium.

Datta, N., and H. C. Deeth. 1999. High pressure processing of milk and dairy products. Aust. J. Dairy Technol. 54:41-46.

Dziuba, J., A. Babuchowski, M. Smoczynski, and Z. Śmietana. 1999. Fractal analysis of caseinate structure. Int. Dairy J. 9:287-292.

Foubert, I., B. Vanhoutte, and K. Dewettinck. 2004. Temperature and concentration dependent effect of partial glycerides on milk fat crystallization. Eur. J. Lipid Sci. Technol. 106:531-539.

Fox, P. F., and P. L. H. McSweeney. 2006. Advanced Dairy Chemistry. Vol. 2: Lipids. P. F. Fox and P. L. H. McSweeney, ed. Springer Sci. Bus. Media Inc., New York, NY.

Frede, E., and W. Buchheim. 2000. The influence of high pressure upon the phase transition behaviour of milk and milk-fat fractions. Milchwissenschaft 55:683-686.

Fredrick, E., D. van de Walle, P. Walstra, J. H. Zijtveld, S. Fischer, P. van der Meeren, and K. Dewettnck. 2011. Isothermal crystalliza- 
tion behaviour of milk fat in bulk and emulsified state. Int. Dairy J. $21: 685-695$.

Gervilla, R., V. Ferragut, and B. Guamis. 2001. High hydrostatic pressure effects on color and milk fat globule of ewe's milk. J. Food Sci. 66:880-885.

Herrera, M. I., and R. W. Hartel. 2000. Effect of processing conditions on crystallization kinetics of a milk fat model system. J. Am. Oil Chem. Soc. 77:1177-1188.

Huppertz, T., A. L. Kelly, and P. F. Fox. 2002. Effects of high pressure on constituents and properties of milk. Int. Dairy J. 12:561-572.

Juśkiewicz, M., J. Kisza, and B. Staniewski. 1993. Wybrane cechy fizykochemiczne mieszanin tłuszczu mlekowego z olejami roślinnymi. Acta Academiae Agriculturae ac Technicae Olstenensis Technologia Alimentarum 25:37-49.

Leman, J., M. Smoczyński, T. Dołgań, and Z. Dziuba. 2005. Fractal analysis of structure of cow and goat beta-lactoglobulin preparations. J. Food Sci. Technol. 42:428-430.

Lopez, C., C. Bourgaux, P. Lesieur, A. Riaublanc, and M. Ollivon. 2006. Milk fat and primary fractions obtained by dry fractionation: 1. Chemical composition and crystallization properties. Chem. Phys. Lipids 144:17-33.

Lopez, C., P. Lesieur, C. Bourgaux, G. Keller, and M. Ollivon. 2001. Thermal and structural behavior of milk fat: 2. Crystalline forms obtained by slow cooling of cream. J. Colloid Interface Sci. 240:150-161.

Lopez, C., and M. Ollivon. 2009. Triglycerides obtained by dry fractionation of milk fat: 2 . Thermal properties and polymorphic evolutions on heating. Chem. Phys. Lipids 159:1-12.

Mandelbrot, B. B. 1982. The Fractal Geometry of Nature. W. H. Freeman, San Francisco, CA.

Martini, S., and M. L. Herrera. 2002. X-Ray diffraction and crystal size. J. Am. Oil Chem. Soc. 79:315-316.

Martini, S., M. L. Herrera, and A. G. Marangoni. 2005. New technologies to determine solid fat content on-line. J. Am. Oil Chem. Soc. 82:313-317.

Peleg, M. 1993. Fractals and foods. Crit. Rev. Food Sci. Nutr. 33:149 165.

Roginski, H., J. Fuquay, and P. Fox. 2003. Encyclopedia of Dairy Science. Acad. Press, London UK.

Rønholt, S., J. J. K. Kirkensgaard, T. B. Pedersen, K. Mortensen, and J. C. Knudsen. 2012. Polymorphism, microstructure and rheology of butter. Effects of cream heat treatment. Food Chem. $135: 1730-1739$.
Shi, Y., M. Smith, and R. W. Hartel. 2001. Compositional effects on milk fat crystallization. J. Dairy Sci. 84:2392-2401.

Smiddy, M. A., T. Huppertz, and S. M. van Ruth. 2012. Triacylglycerol and melting profiles of milk fat from several species. Int. Dairy J. 24:64-69.

Smoczyński, M., and M. Baranowska. 2014. A fractal approach to microstructural changes during the storage of yoghurts prepared with starter cultures producing exopolysaccharides. J. Texture Stud. 45:121-129. http://dx.doi.org/10.1111/jtxs.12055.

Staniewski, B. 2000. Badania nad Wpływem Składu i Właściwości Fizycznych Fazy Tłuszczowej na Reologiczne Cechy Masła. Rozprawy i Monografie. 25 ed. Univ. Warmia Mazury, Olsztyn, Poland.

Staniewski, B., K. Kiełczewska, M. Smoczyński, M. Baranowska, M. Czerniewicz, and W. Brandt. 2012. Effect of high pressures on the composition of milk fat triacylglycerols. Milchwissenschaft $67: 18-21$.

Tietz, R. A., and R. W. Hartel. 2000. Effect of minor lipids on the crystallization and crystal habit of milk fat-cocoa butter and bloom formation. J. Am. Oil Chem. Soc. 77:763-777.

Trujillo, A. J., M. Capellas, J. Saldo, R. Gervilla, and B. Guamis. 2002. Applications of high-hydrostatic pressure on milk and dairy products: A review. Innov. Food Sci. Emerg. Technol. 3:295-307.

Tynek, M., and E. Ledóchowska. 2003. Zmiana właściwości fizycznych tłuszczu mlecznego oraz jego wysokotopliwej frakcji w wyniku przeestryfikowania olejem słonecznikowym. Tłuszcze Jadalne 38:104-117.

Van Aken, G. A., E. Grotenhuis, A. J. van Langevelde, and H. Schenk. 1999. Composition and crystallization of milk fat fractions. J. Am. Oil Chem. Soc. 76:1323-1331.

Verret, C., A. El Moueffak, A. Largeteau, M. Frimigacci, G. Demazeau, F. Leal-Calderon, and M. Cansell. 2009. Effects of high pressure on anhydrous milk fat crystallization in emulsion. High Press. Res. 29:57-60.

Wright, A. J., and A. G. Marangoni. 2006. Crystallization and rheological properties of milk fat. Pages 245-292 in Advanced Dairy Chemistry. Vol. 2: Lipids. P. F. Fox and P. L. H. McSweeney, ed. Springer, New York, NY.

Żegarska, Z. 1988. Badania zależności między składem chemicznym a właściwościami fizycznymi tłuszczu mlekowego. Acta Academiae Agriculturae ac Technicae Olstenensis Technologia Alimentarum (Suppl. D) 22:1-46. 